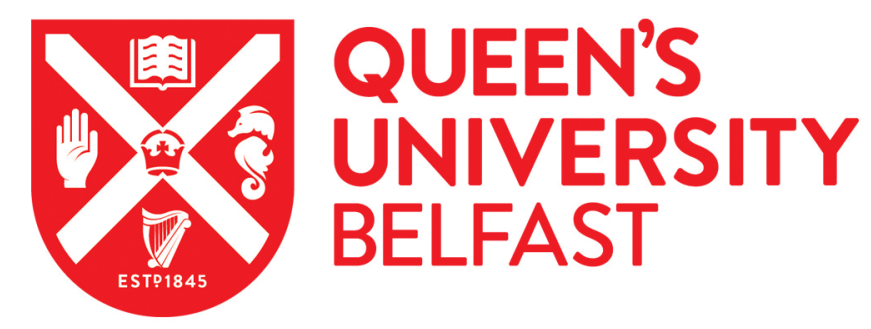

\title{
Toll like Receptor signalling by Prevotella histicola activates alternative NF-KB signalling in Cystic Fibrosis bronchial epithelial cells compared to P. aeruginosa
}

Schock, B. C., Bertelsen, A., \& Elborn, S. J. (2020). Toll like Receptor signalling by Prevotella histicola activates alternative NF-KB signalling in Cystic Fibrosis bronchial epithelial cells compared to P. aeruginosa. PLoS One, 15(10), [e0235803]. https://doi.org/10.1371/journal.pone.0235803

Published in:

PLoS One

Document Version:

Publisher's PDF, also known as Version of record

Queen's University Belfast - Research Portal:

Link to publication record in Queen's University Belfast Research Portal

\section{Publisher rights}

Copyright 2020 the authors.

This is an open access article published under a Creative Commons Attribution License (https://creativecommons.org/licenses/by/4.0/), which permits unrestricted use, distribution and reproduction in any medium, provided the author and source are cited.

\section{General rights}

Copyright for the publications made accessible via the Queen's University Belfast Research Portal is retained by the author(s) and / or other copyright owners and it is a condition of accessing these publications that users recognise and abide by the legal requirements associated with these rights.

Take down policy

The Research Portal is Queen's institutional repository that provides access to Queen's research output. Every effort has been made to ensure that content in the Research Portal does not infringe any person's rights, or applicable UK laws. If you discover content in the Research Portal that you believe breaches copyright or violates any law, please contact openaccess@qub.ac.uk. 


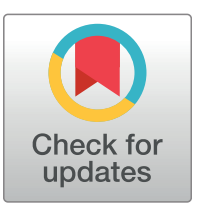

\section{G OPEn ACCESS}

Citation: Bertelsen A, Elborn SJ, Schock BC (2020) Toll like Receptor signalling by Prevotella histicola activates alternative NF-kB signalling in Cystic Fibrosis bronchial epithelial cells compared to $P$. aeruginosa. PLoS ONE 15(10): e0235803. https:// doi.org/10.1371/journal.pone.0235803

Editor: Abdelwahab Omri, Laurentian University, CANADA

Received: June 25, 2020

Accepted: September 17, 2020

Published: October 8, 2020

Peer Review History: PLOS recognizes the benefits of transparency in the peer review process; therefore, we enable the publication of all of the content of peer review and author responses alongside final, published articles. The editorial history of this article is available here: https://doi.org/10.1371/journal.pone.0235803

Copyright: $\odot 2020$ Bertelsen et al. This is an open access article distributed under the terms of the Creative Commons Attribution License, which permits unrestricted use, distribution, and reproduction in any medium, provided the original author and source are credited.

Data Availability Statement: All relevant data are within the manuscript and its Supporting Information files.
RESEARCH ARTICLE

\section{Toll like Receptor signalling by Prevotella histicola activates alternative NF-kB signalling in Cystic Fibrosis bronchial epithelial cells compared to $P$. aeruginosa}

\author{
Anne Bertelsen $^{1,2}$, Stuart J. Elborn ${ }^{1,3}$, Bettina C. Schock $\oplus^{1 *}$ \\ 1 Wellcome-Wolfson Institute for Experimental Medicine, Queens University Belfast, Belfast, United \\ Kingdom, 2 Department of Medicine, University of Cambridge, Addenbrookes Hospital, Cambridge, United \\ Kingdom, 3 Imperial College London, London, United Kingdom \\ * b.schock@qub.ac.uk
}

\section{Abstract}

Cystic Fibrosis (CF), caused by mutations affecting the CFTR gene, is characterised by viscid secretions in multiple organ systems. CF airways contain thick mucus, creating a gradient of hypoxia, which promotes the establishment of polymicrobial infection. Such inflammation predisposes to further infection, a self-perpetuating cycle in mediated by NFKB. Anaerobic Gram-negative Prevotella spp. are found in sputum from healthy volunteers and CF patients and in CF lungs correlate with reduced levels of inflammation. Prevotella histicola ( $P$. histicola) can suppress murine lung inflammation, however, no studies have examined the role of $P$. histicola in modulating infection and inflammation in the CF airways. We investigated innate immune signalling and NF-kB activation in CF epithelial cells CFBE41o- in response to clinical stains of $P$. histicola and Pseudomonas aeruginosa ( $P$. aeruginosa). Toll-Like Receptor (TLR) expressing HEK-293 cells and siRNA assays for TLRs and IKKa were used to confirm signalling pathways. We show that $P$. histicola infection activated the alternative NF-kB signalling pathway in CF bronchial epithelial cells inducing HIF-1 $\alpha$ protein. TLR5 signalling was responsible for the induction of the alternative NF-kB pathway through phosphorylation of IKKa. The induction of transcription factor HIF-1 $\alpha$ was inversely associated with the induction of the alternative NF-kB pathway and knockdown of IKKa partially restored canonical NF-kB activation in response to $P$. histicola. This study demonstrates that different bacterial species in the respiratory microbiome can contribute differently to inflammation, either by activating inflammatory cascades ( $P$. aeruginosa) or by muting the inflammatory response by modulating similar or related pathways ( $P$. histicola). Further work is required to assess the complex interactions of the lung microbiome in response to mixed bacterial infections and their effects in people with CF. 
Funding: $\mathrm{AB}$ received a $\mathrm{PhD}$ studentship from the Department for Employment and Learning (DEL), Northern Ireland, UK (https://www.nidirect.gov.uk/ articles/department-economy-studentships). BCS was supported by a grant from Northern Ireland Chest Heart and Stroke (NICHS, 2014_15) (https:// www.nicva.org/organisation/ni-chest-heart-stroke) The funders had no role in study design, data collection and analysis, decision to publish, or preparation of the manuscript.

Competing interests: The authors have declared that no competing interests exist.

\section{Introduction}

Cystic Fibrosis (CF), is an autosomal recessive life-limiting disease, characterised by viscid secretions in multiple organ systems due to mutations affecting the CFTR gene, which codes for a cAMP-regulated chloride channel, found on epithelial surfaces, including the airways, pancreas, and intestine [1]. To date over 2000 mutations have been described, with a phenylalanine deletion (F508del) being the most common disease-causing mutation (present in $\sim 90 \%$ of PWCF). The main causes of mortality and morbidity in CF are lung damage and progressive lung function decline and, attributed in part to the dehydrated mucus and bacterial infection with Gram-negative pathogens which cause a sustained inflammatory response in the CF lung [2]. The contribution of bacterial species such as Pseudomonas aeruginosa (P. aeruginosa), Burkholderia cepacia complex, Haemophilus influenza and Staphylococcus aureus (S. aureus) to inflammation in the CF lung have been extensively studied [3-5], however, a broader picture of the microenvironment in the CF lung has recently become apparent with advances in high fidelity next generation sequencing (NGS) [1]. This method has identified a diverse microbiome in the lungs of people with CF, including the presence of the Gramnegative anaerobic genus Prevotella spp. [6]. Members of this genus are also found in high abundance in the upper airway of healthy people [7], but its role in the airways is poorly characterised. In people with CF the presence of Prevotella spp. has a positive correlation with higher lung function and reduced C-reactive protein (CRP) [8]. Furthermore, we recently showed that a strain of $P$. nigrescens isolated from a person with CF induced a lower proinflammatory cytokine expression in CF bronchial epithelial cells than P. aeruginosa, suggesting that the presence of certain Prevotella species in CF lungs may lower the inflammatory response and could therefore be beneficial to the host [9].

Interaction of bacterial pathogen the host cells (the airway epithelia cells) results in the activation of Toll-Like Receptors (TLRs) such as TLR2 (recognising mainly Gram-positive bacteria) and TLR4 (recognising mainly Gram-negative bacteria). In airway epithelial cells, such TLR-ligand binding activates NF- $\mathrm{KB}$ signalling leading to the induction of the innate inflammatory response.

$\mathrm{NF}-\kappa \mathrm{B}$ activation occurs via two major signalling pathways, the canonical and the noncanonical NF- $\kappa \mathrm{B}$ signalling pathways. Common to both is the activation of the I $\kappa \mathrm{B}$ kinase (IKK) complex (IKK $\alpha / \mathrm{IKK} \beta)$ [10]. In the canonical signaling pathway, binding of ligands to cell surface receptors such as Toll-like receptors (TLRs) lead to the recruitment of adaptors such as TRAF to phosphorylate IKK. Subsequent phosphorylation and degradation of IкB activates and translocates NF- $\kappa \mathrm{B}$ dimers comprising RelA(p65), c-Rel, RelB and p50 to induce target gene expression [11]. Activation of the non-canonical pathway, involves the two IKK $\alpha$ subunits containing IKK complex, but not NEMO. Ligand-induced activation triggers NF- $\kappa \mathrm{B}$ inducing kinase (NIK) to phosphorylate and activate the IKK $\alpha$ complex. In turn, IKK $\alpha$ phosphorylates p100 leading to the p52/RelB active heterodimer, important e.g. for the generation of B and T lymphocytes. Importantly, to date, only a small number of stimuli are known to activate the non-canonical pathway [12].

In CF airway diseases, the canonical NF- $\kappa B$ signalling pathway, consisting of the $\mathrm{p} 65$ and p50 subunits, and its role in inflammation in CF has been extensively investigated $[9,13,14]$, however, the role of the alternative NF- $\kappa$ B signalling pathway, involving RelB and p52 subunits, has not. Activation of the alternative pathway is known to occur in response to a small set of agonists including lipopolysaccharide (LPS), CD40Ligand and lymphotoxin-alpha (LT$\alpha_{1}$ ). This pathway has been shown to be active in epithelial cells and has recently been implicated in pathway analysis of inflammation in people with CF [15-17]. Inhibitor of kappaB kinase $\alpha(\mathrm{IKK} \alpha)$ plays a role in resolving NF- $\mathrm{KB}$-driven inflammation in TLR expressing cells 
by facilitating turnover of p65 and cRel, removing them from the nucleus [18]. Thereby IKK $\alpha$ activation was also shown to limit the inflammatory response during bacterial infection and inhibit canonical NF- $\kappa B$ activation [18].

Furthermore, mucus plugging and bacterial bio-film development results in the formation of gradients of hypoxia in the CF lung supporting induction of the transcription factor hypoxia induced factor- $1 \alpha(\mathrm{HIF}-1 \alpha)$. The relationship between induction of HIF- $1 \alpha$ and NF- $\kappa$ B signalling indicates that the induction of HIF- $1 \alpha$ may exert a regulatory effect on p65-driven inflammation [19]. However, the effect of HIF- $1 \alpha$ on the alternative NF- $\kappa B$ pathway and possibly the resolution of inflammation is not clearly understood [20].

No studies have examined if infection with P. histicola results in the activation of TLR signalling pathways in CF bronchial epithelial cells and if TLR signalling can directly activate the alternative NF- $\kappa B$ signalling pathway in CF bronchial epithelial cells. As bacterial infection results in NF- $\mathrm{KB}$ signalling and induction of inflammatory cytokines, we hypothesised that $P$. histicola induces TLR signalling contributing to the activation of NF- $\kappa B$ signalling. As the presence of Prevotella spp. in CF lungs correlates with better lung function [8], we further hypothesised $P$. histicola may activate the alternative NF- $\kappa \mathrm{B}$ driven response, which may inhibit canonical NF- $\mathrm{\kappa B}$ activation [21]. These studies demonstrate that $P$. histicola activates the alternative NF- $\mathrm{\kappa B}$ signalling pathway and HIF- $1 \alpha$ in CF bronchial epithelial cells through TLR5 signalling.

\section{Materials and methods}

\section{Bacterial culture}

The bacterial isolates used in this study were all obtained from patients attending the adult $\mathrm{CF}$ clinic at Belfast City Hospital. The isolates were derived from two different patients enrolled in a multicentre study (Office for Research Ethics Committees Northern Ireland (OREC) 10/ NIR01/41; Integrated Research Approval System (IRAS) Project no. 41579) as previously described [17].

The clinical isolate of $P$. histicola B011L was cultured under anaerobic conditions for 72 hours on Columbia Blood Agar (CBA, Fannin LIP) using a Don Whitley anaerobic cabinet (Don Whitley A35 workstation) as described [6]. This lawn of colonies was used to inoculate $10 \mathrm{~mL}$ of anaerobic basal broth (Oxoid)TO OD.0.1 and this was allowed to grow to mid log phase (approximately 18 hours). This culture was used for infection experiments. P. histicola was identified by $16 \mathrm{~S}$ rRNA sequencing, PGFE and RAPD analysis as described [9, 22].

$P$. aeruginosa (clinical isolate B021, identified using $16 \mathrm{~S}$ rRNA screening [22]) was grown under aerobic conditions on Columbia blood agar (CBA) $\left(37^{\circ} \mathrm{C}, 5 \% \mathrm{CO}_{2}, 95 \%\right.$ mixed gas) over night. This culture was then utilised to inoculate a $10 \mathrm{~mL}$ culture of Lysogeny Broth (LB broth), The start OD was 0.05 . This broth culture was incubated for up to two hours at 200 $\mathrm{rpm}, 37^{\circ} \mathrm{C}$ until mid-log phase under aerobic conditions (approximately 3-4 hours) prior to being used for further cell infections under anaerobic conditions.

The minimum amount of bacteria required to provoke a significant response from CFBE41o- cells ( $0-4 \mathrm{~h}$, anaerobic conditions) was determined by screening of 3 different $P$. aeruginosa isolates as described [9]. Growth curves of $P$. histicola and $P$. aeruginosa under anaerobic conditions revealed no differences in the growth rates between the two species (S1 Fig).

\section{Cell culture}

The F508del homozygote cystic fibrosis cell line (CFBE41o-) was maintained in antibiotic free minimum essential media (MEM, Gibco), supplemented with $10 \%$ heat inactivated foetal bovine serum (FBS, Gibco) and 5\% L-Glutamine (Gibco) under standard cell culture 
conditions $\left(37^{\circ} \mathrm{C}, 5 \% \mathrm{CO}_{2}, 95 \%\right.$ mixed gas). All tissue culture flasks and plates were pre-coated with a $1 \%$ PurCol type 1 collagen solution (Nutacon) and passaged as described previously [23]. HEK-293-TLR2, HEK-293-TLR4, HE-293-TLR5 and HEK-293-TLR null cells were maintained as per manufacturer's instructions (InvivoGen).

\section{Infection assays}

CFBE41o- cells were infected with $P$. histicola or P. aeruginosa at an MOI (Multiplicity of Infection) of 100 for 4 hours. Both bacteria were grown to mid log phase as described previously [9]. An MOI of 100 was defined by plating all inocula on CBA agar and enumerating viable counts the following morning. Liquid cultures were used to inoculate cells for infection experiments and cells were incubated for up to 4 hours under anaerobic conditions as described above. Cells were incubated under anaerobic conditions for the duration of the experiments as described in supplementary data (S1 Text).

\section{Cell viability assays}

To confirm that experimental conditions would not negatively affect cell viability, lactate dehydrogenase release (LDH, Abcam), mitochondrial respiration (MTT) and trypan blue exclusion were assessed after exposure to hypoxia and bacteria.

Briefly, bell death was assessed by measuring LDH release from infected cells and non-infected control cells. $10 \mu \mathrm{L}$ of supernatant was used for each assay as per manufacturer's instructions (Abcam, ab69693). Analyses of mitochondrial activation (measured by MTT (3- [4, 5-dimethyl thiazol-2yl]-2, 5 diphenyl tetrazolium bromide) conversion to purple formazan (absorbance $\lambda=$ $570 \mathrm{~nm}$ )) served as a surrogate for cell viability. Trypan Blue (Sigma) was used in the dye exclusion assay. After incubation and loading onto a Neubauer haemocytometer, cells which appeared blue under the microscope were determined as 'dead' and cells appearing white were counted as 'live cells. Further details of these assays can be found in the supplement (S2A-S2C Fig).

\section{TLR reporter assays}

HEK-293-TLR2, HEK-293-TLR4 and HEK-293-TLR5 cells were purchased from InvivoGen and cultured and transfected as per manufacturer's instructions. Briefly, HEK-293 cells were

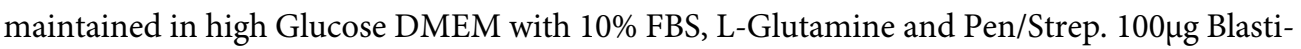
cidin was added to cells after the second passage and cells were maintained in the media thereafter. Cells were transiently transfected with an NF- $\mathrm{\kappa B}$ containing reporter construct plasmid (LyoVec and pNifty-Luc ${ }^{\mathrm{m}}$, InvivoGen) and cells were incubated for 24 hours under standard tissue culture conditions to recover from the transfection. Bacterial infection was carried out as described [9] and cells were incubated under anaerobic conditions for the duration of the experiments.

\section{Cytoplasmic and nuclear fraction extraction for DNA binding ELISA}

CFBE41o- cells were infected with either P. aeruginosa or P. histicola as described. DNA-binding ELISAs (enzyme-linked immunosorbent assays) were commercially sourced. (i) IKK $\alpha$ : Solid phase ELISA (Cell signal, CST, PathScan Phospho-IKK $\alpha$ ). IKK $\alpha$ was quantified from all samples at 0-240 minutes as per manufacturer's instructions. (ii) IкB $\alpha$ (Inhibitor of kappa-B alpha): Sandwich ELISA to quantify phosphorylated I $\kappa \alpha \alpha$ in infected and non-infected cells at

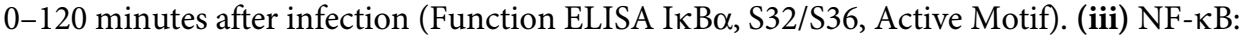
DNA-binding ELISA to quantify active p65, p50, RelB and p52 subunits in infected and non- 
infected cells (Trans/AM NFKB, Activ Motif). Nuclear cell fractions were generated using the NE-Per ${ }^{\mathrm{TM}}$ nuclear and cytoplasmic extraction reagents (Thermo Fisher Scientific).

\section{RT-PCR for TLR and cytokine gene expression}

Total RNA was extracted from infected and un-infected control cell populations using a combination of TRIzol ${ }^{\text {mit }}$ extraction reagent and column extraction as per manufacturer's instructions (Ambion/Thermo Fisher Scientific). Deoxyribonuclease (DNAse) digestion was carried out as per manufacturer's instructions using DNAse 1 (Thermo Fisher Scientific) for each sample. Reverse transcription was carried out using $0.5 \mu \mathrm{g}$ total RNA for each reaction (Superscript III reverse transcription kit, Thermo Fisher Scientific).

Quantitative reverse transcription PCR (qRT-PCR) analysis was carried out on an MX300-P (Agilent technologies) using gene specific primers (QuantiTect $\AA$, Qiagen) and SyBr Green PCR master mix (Thermo Fisher Scientific) as per manufacturer's instructions. The endogenously expressed beta-2-microglobulin (B2M) was used as a house-keeping gene in all experiments. Relative gene expression was calculated as $2^{\wedge}-\Delta \Delta C T$.

\section{siRNA knockdown assays}

Silencer RNA (siRNA) targeted against TLR2, TLR5, scrambled siRNA and siRNA targeted against IKK $\alpha$ (Silencer select, Thermo Fisher Scientific). Lipofectamine 2000 was utilised and reverse transfection was used in all siRNA assays (Thermo Fisher Scientific). Target gene and protein expression were assessed at $24-48$ hours post transfection. Lipofectamine did not induce any significant increase in LDH release (S3 Fig). SiRNA and Lipofectamine concentrations were optimised to induce a significant reduction in target gene expression (S4A Fig) and subsequent cytokine release (S4B Fig).

\section{Statistical analysis}

All statistical analyses were performed using GraphPad Prism (v5.0; GraphPad, San Diego, CA). All data are expressed as mean $+/$ - standard deviation (SD). Parametric tests including Student's t-test were employed to assess the null hypothesis. Where more than two groups were compared either one- or two-way ANOVA was utilised to assess differences between the mean or differences between matched samples with a post-hoc Bonferroni analysis performed for all tests utilising one-way ANOVA.

Further information to materials \& methods can be found in the supplement (S1 Text).

\section{Results}

\section{Inflammatory pathway analyses for $P$. histicola}

To test the hypothesis that infection with P. histicola in CF airway epithelial cells may contribute to anti-inflammatory signalling through activation of the alternative NF- $\mathrm{\kappa B}$ pathway we compared NF-KB signalling in CFBE41o- cells infected with $P$. histicola and $P$. aeruginosa.

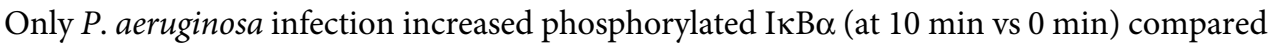
to non-infected control cells $(\mathrm{p}<0.01)$, which returned to baseline at $30 \mathrm{~min}$ post infection (Fig 1A). Infection with $P$. aeruginosa also induced significantly higher levels of nuclear p65-DNA binding ( 2 and 4 hours, $\mathrm{p}<0.001$ and $\mathrm{p}<0.01$, Fig $1 \mathrm{~B}$ ) and significantly higher nuclear p50-DNA binding in response to infection (at 4 hours, $\mathrm{p}<0.001$, Fig $1 C$ ), but $P$. aeruginosa did not change nuclear RelB- or p52-DNA binding (Fig 1D and 1E). In contrast, CFBE41o- cells infected with $P$. histicola did not demonstrate elevated levels of phosphorylated $\mathrm{I} \kappa \mathrm{B} \alpha$ at any time point and there was no change in nuclear $\mathrm{p} 50$ or $\mathrm{p} 65$ in response to infection 
A

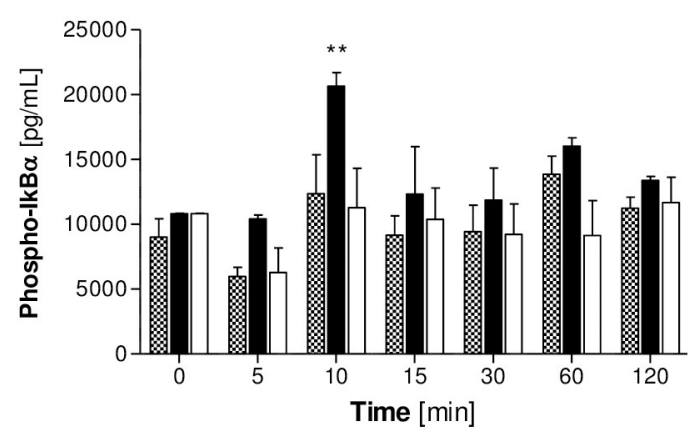

B

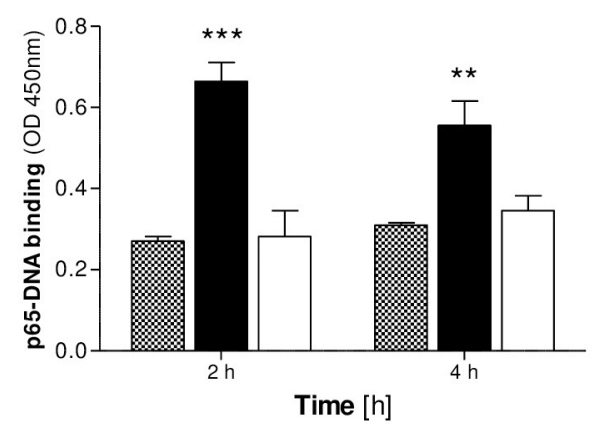

D

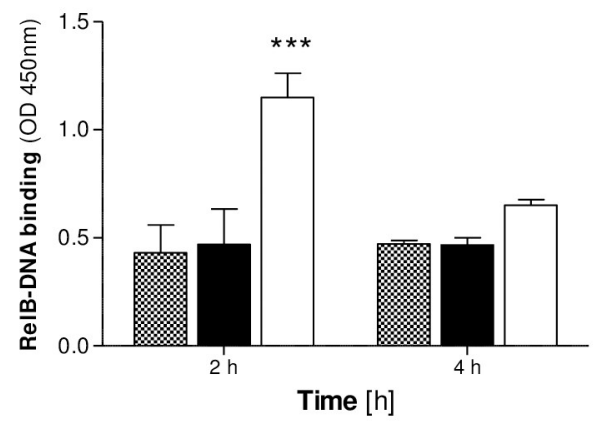

C

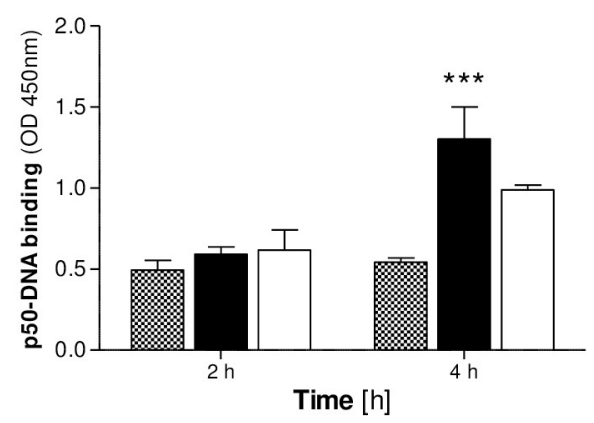

E

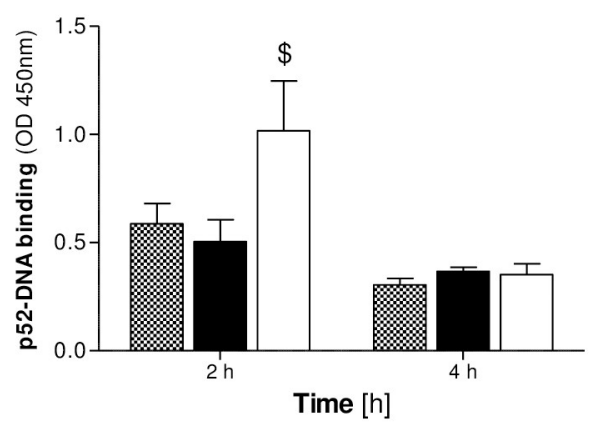

F

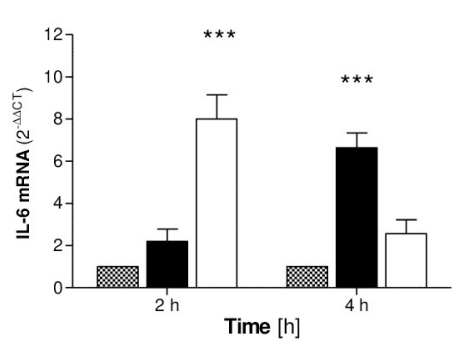

G

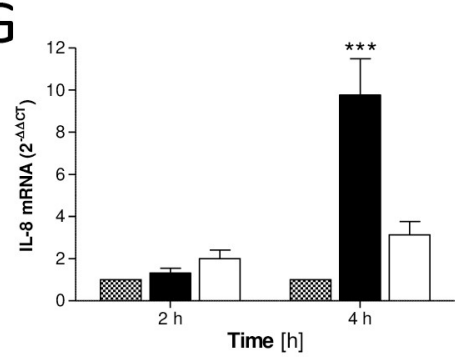

$\mathrm{H}$

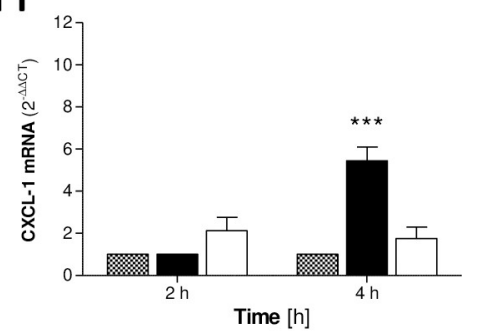

\% Control

P.aeruginosa

P.histicola

Fig 1. P. histicola-Inflammatory pathway analyses. CFBE41o- cells were infected with P. aeruginosa or P. histicola (MOI 100 for up to 4 hours, anaerobic conditions). A: Quantification of phosphorylated $\mathrm{I} \kappa \mathrm{B} \alpha(\mathrm{pg} / \mathrm{mL})$ in CFBE41o- cells infected with P. aeruginosa or P. histicola 0-60 minutes post infection. The DNA-binding abilities of p65, RelB and p52 were determined 2- and 4-hours post infection. B: DNA binding of p65 in infected and non-infected CFBE41o- cells. C: DNA binding of p50 in response to infection in CFBE41o- cells. D: RelB-DNA-binding in response to infection in CFBE41o- cells. E: DNA-binding of p52 in infected CFBE41o- cells. Quantitative RT-PCR using SyBr Green was carried out to determine mRNA 
expression Beta-2-microglobulin was used as the endogenously expressed house-keeping gene for all experiments and $2^{-\Delta \Delta C T}$ was calculated for F: IL-6 mRNA, G: IL-8 mRNA and H: CXCL-1. 2-Way ANOVA with Bonferroni post-test, $\mathrm{n}=3-5,{ }^{*} \mathrm{p}<0.05,{ }^{* *} \mathrm{p}<0.01$ and ${ }^{* * *} \mathrm{p}<0.001$ compared to noninfected CFBE41o-.

https://doi.org/10.1371/journal.pone.0235803.g001

(Fig 1A-1C). However, significant levels of nuclear RelB were observed in response to infection with $P$. histicola $(2$ hours, $\mathrm{p}<0.001$ ) with a reduction at 4 hours post infection compared to baseline controls (Fig 1D). Additionally, nuclear p52-DNA binding was increased 2 hours post infection with $P$. histicola with a significant reduction observed by 4 hours post infection $(\mathrm{p}<0.05$, Fig $1 \mathrm{E})$.

As we did not observe nuclear p65-DNA binding in response to infection with $P$. histicola, we hypothesised that infection with $P$. histicola would not result in transcription of NF- $\kappa \mathrm{B}$ driven inflammatory cytokines. While $P$. aeruginosa infection resulted in significant induction of gene expression for interleukin (IL-)6, IL-8 and CXCL-1 in CFBE41o- cells (4 hours, Fig $1 \mathrm{~F}-1 \mathrm{H})$, there was no IL-8 or CXCL-1 gene induction in response to infection with $P$. histicola at any time point (Fig $1 \mathrm{G}$ and $1 \mathrm{H}$ ). A significant increase in IL-6 gene expression was observed in CFBE41o- cells at 2 hours in response to infection with P. histicola ( $\mathrm{p}<0.001$, Fig $1 \mathrm{~F})$.

Taken together, these data indicate that $P$. histicola infection in CFBE41o- cells results in activation of the alternative NF- $\kappa B$ signalling pathway with no activation of the classic NF- $\kappa B$ pathway.

\section{P. histicola infection and TLR activation}

P. aeruginosa signalling via TLR4 and TLR5 is well-established [24, 25], but little is known about Prevotella-induced TLR signalling. Therefore, to establish events upstream of NF- $\mathrm{\kappa B}$ signalling utilised by $P$. histicola, we first investigated TLR receptor activation.

HEK-293-TLR4 cells demonstrated TLR4 signalling in response to infection with P. aeruginosa only ( $1-4$ hours post infection, $\mathrm{p}<0.001)$, but no TLR4 signalling was observed after infection with $P$. histicola (Fig 2A). HEK-293-TLR2 cells showed TLR2 signalling 2 and 4 hours after $P$. histicola infection (both $\mathrm{p}<0.001$, Fig $2 \mathrm{~B}$ ). P. aeruginosa infection lead to TLR2 signalling 4 hours after infection only ( $\mathrm{p}<0.01$, Fig $2 \mathrm{~B})$.

Furthermore, using HEK-293-TLR5 cells we observed TLR5 signalling 2 and 4 hours post infection with $P$. aeruginosa $(\mathrm{p}<0.01$ and $\mathrm{p}<0.001)$ and also after $P$. histicola infection $(\mathrm{p}<0.001$ and $\mathrm{p} 0.01$ ) with a significant reduction at 4 hours compared to 2 hours ( $<0.01$, Fig $2 \mathrm{C}$ ).

To confirm that TLR2 and TLR5 signalling following P. histicola infection would lead to NF- $\mathrm{KB}$ activation, CFBE41o- cells were transiently transfected with siRNA targeted against TLR2 or TLR5 and infected with P. histicola. In response to infection we observed reduced levels of RelB DNA-binding in cells transfected with siRNA targeted against TLR5 ( $\mathrm{p}<0.001$, Fig 2D), but not when cells were transfected with siRNA targeted against TLR2 (Fig 3D). We also did not find any significant reduction in RelB DNA-binding in response to flagellin stimulation in these cells. However, flagellin alone significantly induces p65-DNA binding in CFBE41 cells ( $\mathrm{p}<0.001$, Fig 2E), but has no effect on RelB-DNA binding (Fig 2D). As a control, P. aeruginosa infection in TLR2 and TLR5 transfected cells did not lead to any significant changes in nuclear p65-DNA binding (Fig 2E).

Overall, these results show that $P$. histicola engages with CF epithelial cells via TLR5 and does not engage TLR2 signalling.

\section{IKKa in P. histicola infection}

A role for IKK $\alpha$ in the regulation of canonical NF- $\kappa B$-driven inflammation in macrophages has been described previously [18], but a role in the alternative NF- $\mathrm{BB}$ signalling is not known. 
A

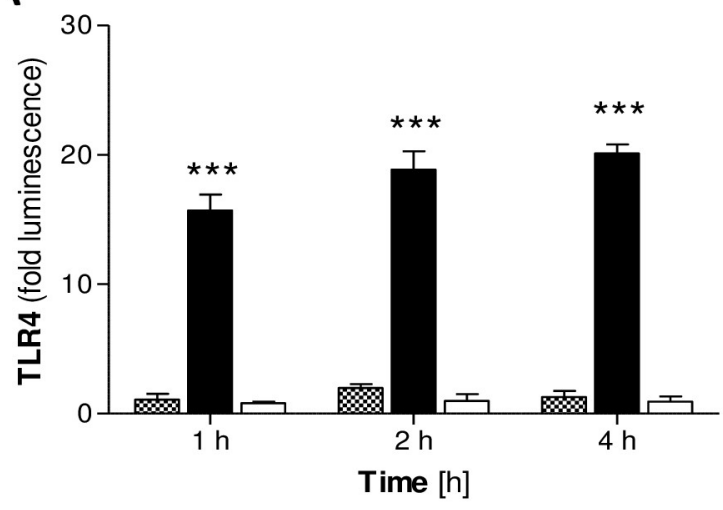

B

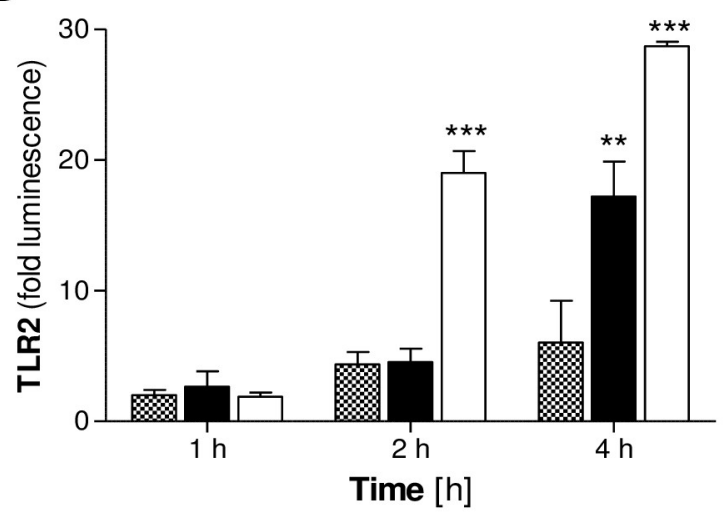

C

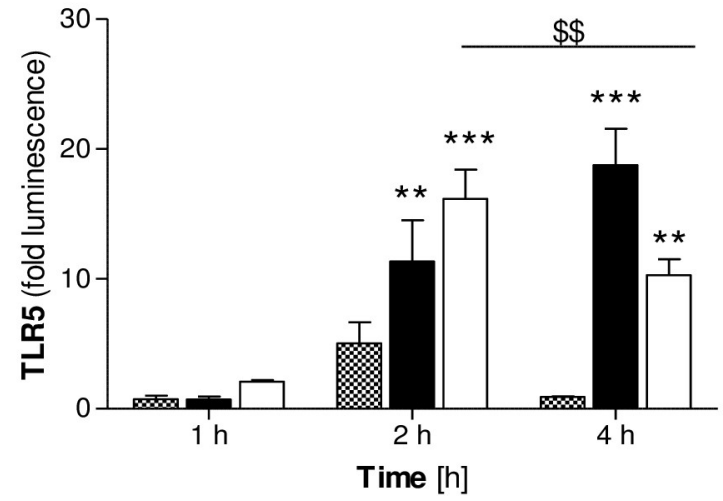

$\mathrm{E}$

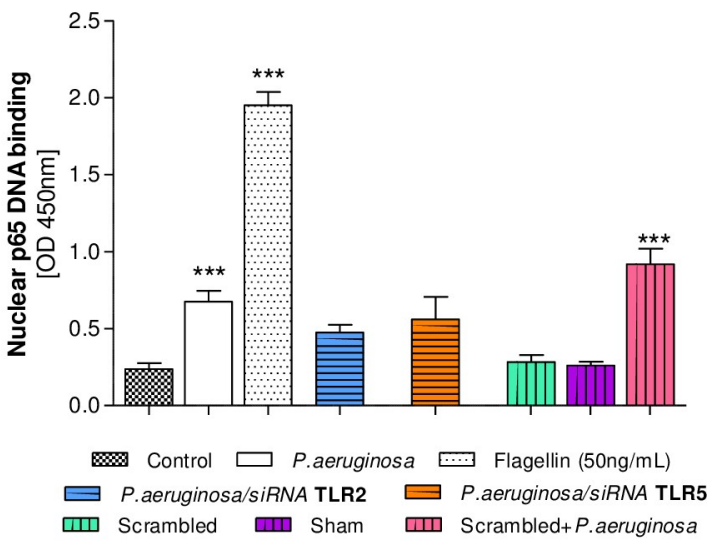

Fig 2. P. histicola-TLR pathway signalling analyses. Luminescence release from HEK-293-TLR2, HEK-293-TLR4, HEK-293-TLR5 or HEK293-TLRnull cells was determined at up to 4 hours post infection normalised to the results observed from HEK-293-TLRnull cells. A: TLR4 signalling, B: TLR2 signalling; C: TLR5 signalling. 2-Way ANOVA with Bonferroni post-test, $\mathrm{n}=3-5,{ }^{* *} \mathrm{p}<0.01$ and ${ }^{* * *} \mathrm{p}<0.001$ compared to noninfected CFBE41o-. CFBE41o- cells (infected with P. aeruginosa, flagellin or P. histicola under anaerobic conditions (MOI 100 for up to 4 hours) were transiently transfected with siRNA targeted against TLR2, TLR5, a scrambled transfection or a sham transfection. Nuclear protein was extracted 2 hours post infection and RelB-DNA binding was determined in transfected and non-transfected cells. D: Nuclear RelB-DNA binding in TLR2 and TLR5 siRNA transfected CFBE41o- cells. E: Nuclear p65-DNA binding in TLR2 and TLR5 siRNA transfected CFBE41o- cells. 1-Way ANOVA with Bonferroni post-test, $\mathrm{n}=3-9,{ }^{* * *} \mathrm{p}<0.001$ compared to non-infected CFBE41o-; ${ }^{\$ \$} \mathrm{p}<0.001$ compared to $P$. histicola.

https://doi.org/10.1371/journal.pone.0235803.g002 
To investigate the role of IKK $\alpha$ in NF- $\mathrm{KB}$ signalling, we determined phosphorylated IKK $\alpha$ in $P$. histicola infection and in CFBE41o- cells with transient IKK $\alpha$ knock down. CFBE41o- cells rapidly elevated phosphorylated IKK $\alpha$ in response to infection with $P$. histicola (5-60 min, $\mathrm{p}<0.05, \mathrm{p}<0.001$, Fig $3 \mathrm{~A}$ ), while infection with $P$. aeruginosa resulted in phosphorylation of IKK $\alpha$ at 60 minutes post infection only ( $<<0.001$, Fig $3 A$ ). siRNA knockdown of IKK $\alpha$ resulted in a significant reduction in the DNA-binding abilities of nuclear RelB in response to infection with $P$. histicola $(\mathrm{p}<0.001$, Fig $3 \mathrm{~B})$. As expected, $P$. aeruginosa infection significantly induced p65-DNA binding ( $\mathrm{p}<0.001$, Fig $3 \mathrm{C}$ ), but $P$. histicola infection did not (scrambled IKK $\alpha$ siRNA and P. histicola, Fig 3C). siRNA IKK $\alpha$ in P. histicola infected CFBE41o- had no inducing effect on p65-DNA binding in CFBE41o-, and p65-DNA levels remained significantly lower compared to those in $P$. aeruginosa infected cells ( $\mathrm{p}<0.001$, Fig $3 \mathrm{C})$. Our results confirm a role for $P$. histicola-induced IKK $\alpha$ in alternative NF- $\kappa \mathrm{B}$ signalling.

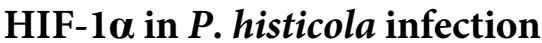

HIF- $1 \alpha$, induced in response to anaerobic conditions, is thought to have a regulatory effect on NF- $\kappa B$ [26]. Therefore, we assessed if HIF- $1 \alpha$ influenced NF- $\kappa B$ activation in response to infection with $P$. histicola. CFBE41o- cells had increased levels of HIF-1 $\alpha$ protein in response to infection with $P$. histicola ( 1 and 4 hours, both $\mathrm{p}<0.01$, Fig 4 A). When CFBE41o- cells were transfected with siRNA targeting TLR2, intracellular HIF- $1 \alpha$ levels remained elevated. However, in cells transfected with siRNA targeting TLR5, HiF- $1 \alpha$ was significantly reduced in response to infection with $P$. histicola (30 min, $\mathrm{p}<0.001$, Fig 4B) suggesting that $P$. histicola induced TLR 5 signalling was mediated by HIF- $1 \alpha$.

\section{Discussion}

In CF airways, infections with bacterial species such as $P$. aeruginosa, Burkholderia cepacia complex, Haemophilus influenza and S. aureus are well investigated [3-5]. However, advances in NGS have identified the presence of Prevotella spp. in the lungs of people with CF [6]. Moreover, no studies have examined the ability of TLR signalling to activate the alternative NF- $\kappa B$ signalling pathway or the role of transcription factor HIF- $1 \alpha$ in this CF bronchial epithelial cells response [27]. Therefore, this study was set out to investigate the contribution of Prevotella spp. (P. histicola) in TLR and NF- $\mathrm{KB}$ signalling to CF airways inflammation.

The relative abundance of anaerobic bacteria compared to aerobic bacteria in CF sputum is associated with a milder disease when compared to Pseudomonas-dominated patients. In this large multisite study involving clinical stable CF patients from the UK, Ireland and the US, Muhlebach et al. showed the culture of 18 anaerobic genera from 59\% of sputum samples (95\% aerobic). Significantly prevalent anaerobes were Prevotella species, followed by Veillonella, Porphyromonas and others. Importantly, the prevalence of anaerobes was positively associated with pancreatic sufficiency, better nutrition and better lung function [28]. Consistent with this, reduced bacterial diversity and increased levels of inflammation have also been reported in patients with CF $[8,29]$. A lower abundance of aerobic and anaerobic bacteria reflecting microbiota disruption was also shown to be associated with disease progression (lower lung clearance index (LCI) and higher CRP in the CF lung [29]. Zemanick et al. investigated the presence of anaerobes in early CF exacerbations showing the highest relative abundance for Prevotella, Veillonella and Porphyromonas. Higher levels of sputum anaerobes were associated with less inflammation and higher lung function compared to the presence of Pseudomonas at exacerbation [8]. However, hile the weak inflammatory properties of commensal Prevotella spp. might help the airways' immune system tolerate colonisation [30], P. histicola has also been shown to exert anti-inflammatory properties in a murine model of rheumatoid 
A

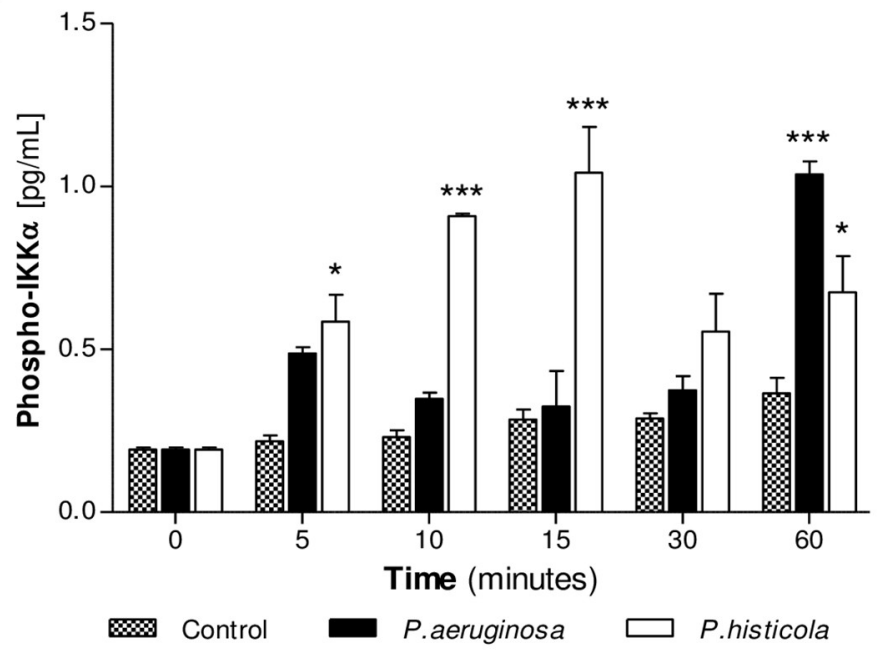

B

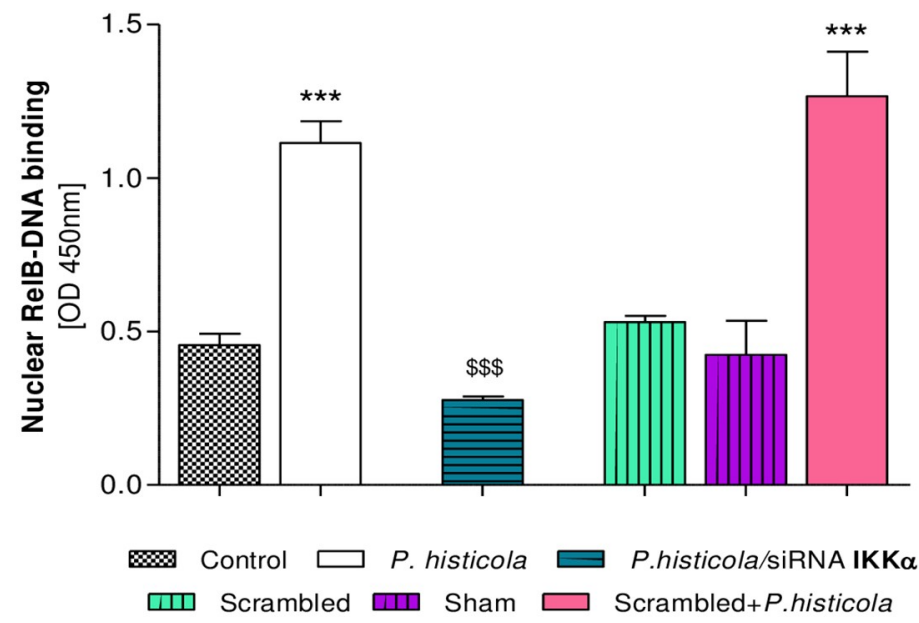

C

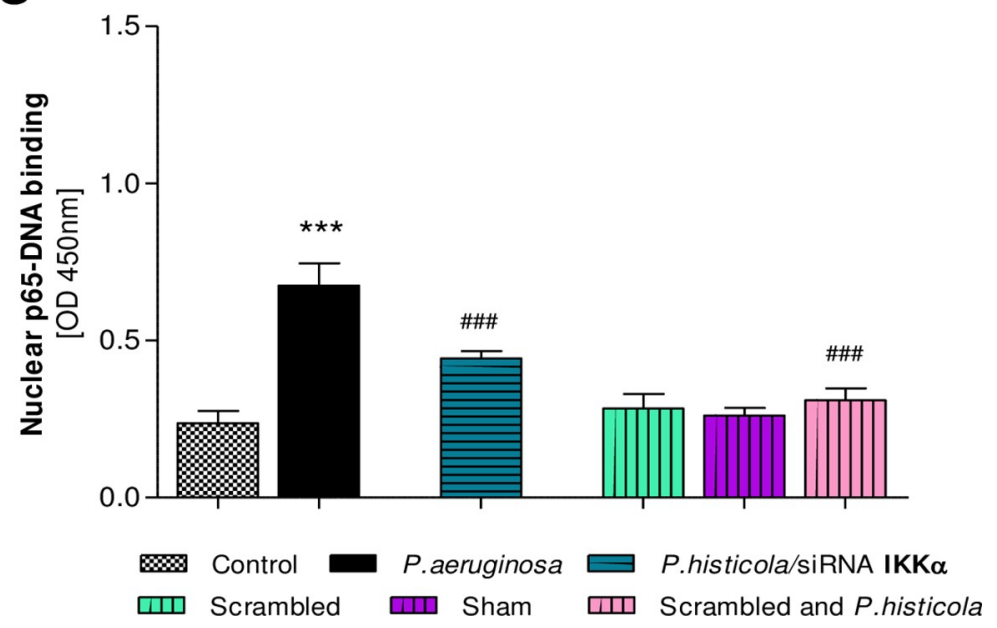


Fig 3. IKKa in P. histicola infection. Phosphorylated IKK $\alpha$ in infected and non-infected CFBE41o- cells (MOI 100, $P$. aeruginosa and $P$. histicola) determined at 0-60 minutes. CFBE41o- cells were also transiently transfected with siRNA targeted against IKK $\alpha$. RelB and p65-DNA binding was determined in P. histicola infected cells (MOI 100, for 2 hours). A: Time course IKK $\alpha$ phosphorylation in CFBE41o- cells in response to infection. 2-Way ANOVA with Bonferroni post-test, $\mathrm{n}=3-5,{ }^{*} \mathrm{p}<0.05$ and ${ }^{* * *} \mathrm{p}<0.001$ compared to non-infected CFBE41o-. B: Nuclear RelB-DNA binding in response to transfection with IKK $\alpha$ siRNA and infection with $P$. histicola. C: Nuclear p65-DNA binding in response to transfection with IKK $\alpha$ siRNA and infection with P. histicola. 1-Way ANOVA with Bonferroni post-test, $\mathrm{n}=3-9,{ }^{* * *} \mathrm{p}<0.001$ compared to non-infected CFBE41o-; ${ }^{\$ \$} \mathrm{p}<0.001$ compared to P. histicola (RelB) or P. aeruginosa (p65).

https://doi.org/10.1371/journal.pone.0235803.g003

arthritis [31]. Our data confirm that $P$. histicola contributes to anti-inflammatory signalling, facilitated through activation of the alternative NF- $\mathrm{\kappa B}$ pathway via RelB and $\mathrm{p} 52$, while P. aeruginosa signalling is through $\mathrm{I} \kappa \mathrm{B} \alpha$ phosphorylation and p65/p50 activation.

Hypoxia can affect bacterial growth and Schaible et al. showed that $P$. aeruginosa growth was slower under hypoxic conditions than under normoxic conditions [32]. However, comparing $P$. histicola and $P$. aeruginosa under anaerobic conditions revealed no differences in growth rates between the two species (S1 Fig), suggesting that any differences described are a direct result of a different pathway activation.

Our subsequent investigation of TLR receptor activation demonstrated a role for $P$. histicola in TLR5-induced activation of the alternative NF- $\kappa \mathrm{B}$ signalling in CF bronchial epithelial cells. Additionally, we demonstrate a role for IKK $\alpha$ and the induction of HIF- $1 \alpha$ in regulating CF inflammation. TLR signalling and the resulting inflammation has been extensively studied in CF. TLRs (especially TLR2, 4 and 5) in the CF lung are one of the most common innate immune defences activated in response to infection leading to the activation of the classical NF-kB-activation and subsequent pro-inflammatory cytokine release [33-36].

Using TLR transfected HEK-293 reporter cells, we have shown that $P$. histicola infection induced TLR2 signalling (at 4 hours) and importantly a rapid induction in TLR5 signalling, which was significantly reduced by the end of the 4 hour infection period. Having established the TLR signalling route of $P$. histicola in CF bronchial epithelial cells, we further investigated the downstream signalling. Infection with $P$. histicola resulted in the induction of RelB and p52 protein but not $\mathrm{p} 65$ or $\mathrm{p} 50$ protein, clearly indicating the induction of the alternative NF$\kappa \mathrm{B}$ pathway. Alternative NF- $\mathrm{B}$ signalling is involved in cell survival and proliferation and has been shown to have anti-inflammatory effects. Studies in RelB deficient mice demonstrated an anti-inflammatory role for RelB [37, 38]. In human lung fibroblasts, RelB overexpression reduced IL-1 $\beta$-induced inflammation [39]. Furthermore, RelB has been linked to the development of tolerance in THP-1 cells [40] through repression of TNF $\alpha$ and Il-1 [41]. Mechanistically, RelB may regulate $\mathrm{IkB} \alpha$ stability and may thereby limit the canonical NF-kB activation [42]. Others have suggested that RelB may interfere with NF-kB activity in the nucleus through protein-protein interactions with RelA to form inactive complexes leading to down-regulation

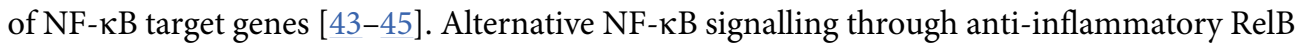
may therefore explain why in patients with CF Prevotella spp. in sputum have been associated with improved lung function and reduced inflammation in CF [8]. This is further supported by our findings that gene expression of the canonical NF-KB-dependent cytokines IL-8 and CXCL-1 were not observed at any time point in response to infection with $P$. histicola.

Increased IL-6 gene expression was observed at 2 hours post infection with $P$. histicola with a reduction at 4 hours, indicating a possible role for the alternative NF- $\kappa B$ signalling pathway in the regulation of IL- 6 gene expression, or/and a role for IKK $\alpha$ in the regulation of IL- 6 gene expression [46].

Our data demonstrate signalling through TLR5 by the clinical $P$. histicola strain used. The siRNA experiments not only confirmed the activation of TLR5 signalling in CF bronchial 

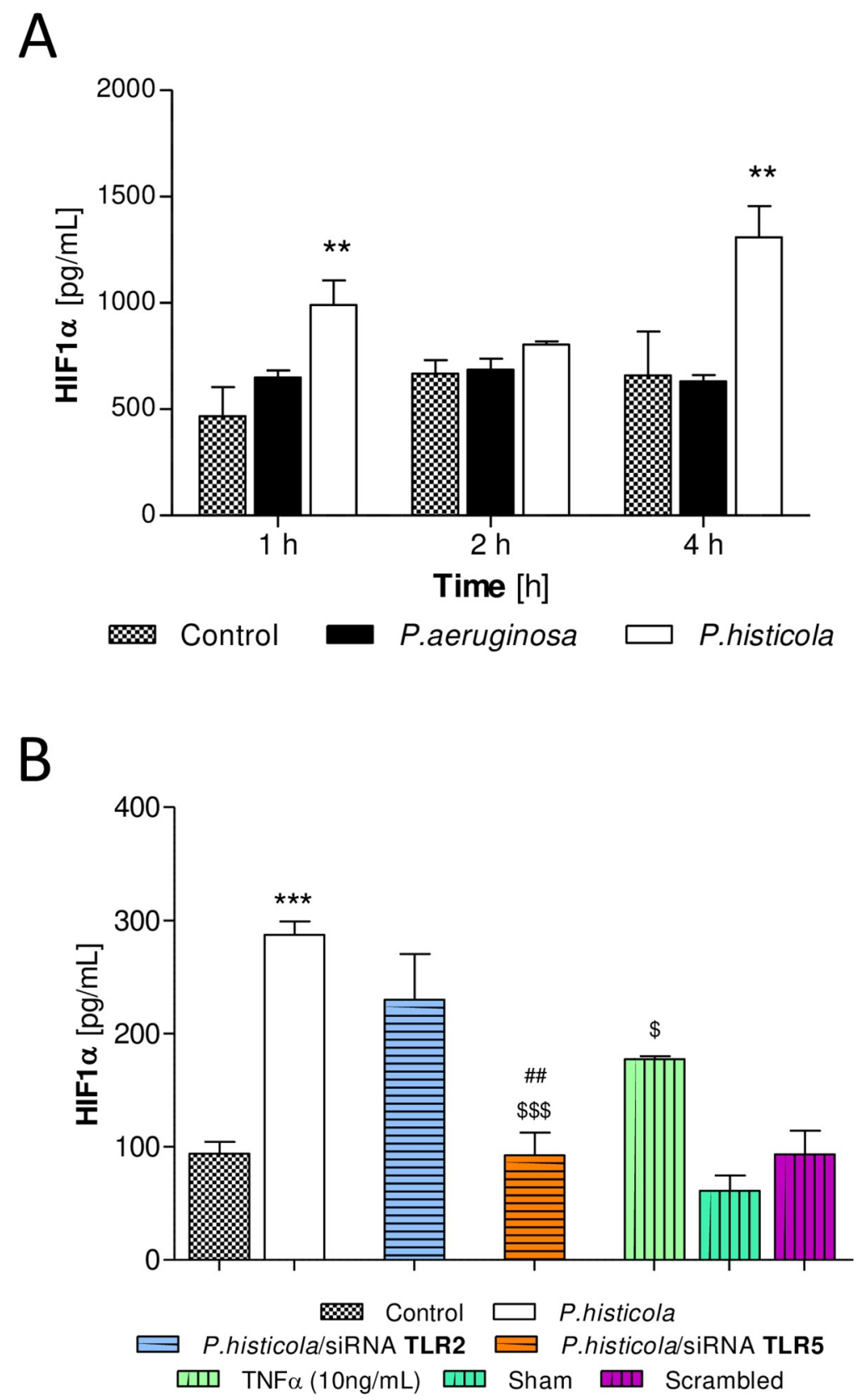

Fig 4. HIF-1 $\alpha$ in P. histicola infection. A: Time course HIF- $1 \alpha$ protein induction in CFBE41o- cells in response to infection. CFBE41o- cells were transfected with P. aeruginosa or P. histicola (MOI 100) and incubated under anaerobic conditions for up to 4 hours. Total HIF- $1 \alpha$ protein was determined at 1,2 and 4 hours post infection. 2-Way ANOVA with Bonferroni post-test, $\mathrm{n}=3,{ }^{*} \mathrm{p}<0.01$ compared to non-infected CFBE41o-. B: CFBE41o- cells were transiently transfected with siRNA targeted against TLR2 and TLR5, infected with P. histicola (MOI 100) and incubated under anaerobic conditions for 30 minutes. Total HIF- $1 \alpha$ protein was determined in transfected and non-transfected cells in response to infection. 1-Way ANOVA with Bonferroni post-test, $\mathrm{n}=4,{ }^{* * *} \mathrm{p}<0.001$ compared to non-infected CFBE41o; ${ }^{\$} \mathrm{p}<0.05,{ }^{\$ \$} \mathrm{p}<0.001$ compared to P. histicola; ${ }^{\# \#}<0.01$ P. histicola/siRNA TLR2 vs TLR5.

https://doi.org/10.1371/journal.pone.0235803.g004

epithelial cells in response to $P$. histicola, but also that the induction of RelB in P. histicola infection was a downstream result of TLR5 signalling. Using flagellin alone to activate TLR5, we clearly show that such activation leads to NF- $\mathrm{kB}(\mathrm{p} 65)$ activation and does not include activation of RelB. So far, flagellin is the main ligand identified for TLR5 [47]. In P. aeruginosa 
flagellin signalling through TLR5 is well-established $[48,49]$ and induces the canonical proinflammatory NF- $\mathrm{KB}$ pathway [50-52]. In several Prevotella species none or only one flagella synthesis pathway gene has been identified [53]. Therefore, our data may suggest that Prevotella spp. could use other structures for attachment and motility and TLR5 engagement. In support of this, recent work in neurons and neuropathic pain strongly suggests TLR5 activation could also be facilitated by non-flagellin small molecules [54]. Further, H. pylori has been shown to activate TLR5 through CagL, a component of its type IV secretion system, which acts as a flagellin-independent TLR5 activator [55]. While our experiments show TLR5 signalling by $P$. histicola, we did not further investigate flagellin expression in the $P$. histicola strain used, nor did we investigate non-specific TLR5 activation in our experimental cell model. Furthermore, we used flagellin derived from Salmonella, which was highly pro-inflammatory, but we cannot exclude that other flagellins (e.g. from $P$. aeruginosa) may provoke a response of different intensity.

As we observed a strong phosphorylation of IKK $\alpha$ induced by $P$. histicola, we further sought to establish if such IKK $\alpha$ activation was involved in the activation of the alternative NF- $\mathrm{KB}$ signalling pathway and if this would have any regulatory effect on the canonical pathway. Knockdown of IKK $\alpha$ significantly reduced $P$. histicola induced activation of the alternative NF- $\mathrm{\kappa B}$ signalling (RelB-DNA binding), but we saw an induction in p65 (see 'scrambled and P. histicola' in Fig 3C) indicating a role for IKK $\alpha$ in the regulation and suppression of $\mathrm{p} 65$.

In normoxia, HIF expression is regulated through hydroxylation by prolyl-4-hydroxylases (PHDs) and subsequent polyubiquitination promotes HIF degradation [56]. However, epithelial stretch has been shown to stabilise HIF1 $\alpha$ (through inhibition of succinate dehydrogenase (SDH) [57]. During hypoxia, the activity of PHDs is suppressed, allowing HIF-1 $\alpha$ to translocate into the nucleus where it binds to its dimerization partner HIF1B and enhances the transcription of HIF target genes [56]. HIF-1 $\alpha$ stabilization during hypoxia is achieved through RSUME/SUMO, where RSUME (RWD-containing sumoylation enhancer) increases the conjugation of SUMO (small ubiquitination modifier) and stabilizing HIF-1 $\alpha$ [26]. IKB $\alpha$ is similarly stabilized during hypoxia, inhibiting NF- $\mathrm{\kappa B}$ activation and signalling, indicating a role for hypoxia induced HIF- $1 \alpha$ in the regulation of NF- $\mathrm{\kappa B}$ [26]. In support of this regulatory function of HIF- $1 \alpha$, pharmacological in vivo studies in acute lung injury (ALI) have shown that HIF-1 $\alpha$ stabilization attenuates pulmonary oedema and lung inflammation [57]. In our study HIF-1 $\alpha$ protein was induced in response to infection with $P$. histicola (in hypoxic conditions) mediated by TLR5, suggesting that TLR5 in addition to inducing inflammation may also have a regulatory role in the inflammatory response through HIF- $1 \alpha$. HIF- $1 \alpha$ activation induces several cytokines such as TNF $\alpha$, IL-1, IL-4, IL-6 and IL-12 [58]. After P. histicola infection, we show a significant upregulation of IL- 6 expression, a cytokine known for both proinflammatory and anti-inflammatory actions [59].

Furthermore, RelB may exert a suppressive effect on HIF- $1 \alpha$ as we observed an inverse relationship between IKK $\alpha$ induction (Fig 3A) and HIF-1 $\alpha$ expression (Fig 4A). However, as we have analysed total HIF1 $\alpha$, further research will be required to substantiate this hypothesis.

Limitations to the experimental design include the inability of the CFBE41o- cells to remain viable and responsive to infection past four hours. In contrast, a study by Schaible et al. acclimatised airway epithelial cells to hypoxia by incubation in hypoxic condition for 24 hours, although for CFBE41o- cells no information of cell viability is given [32]. Using 3 different assays to determine cell viability (MTT formation, LDH release, trypan Blue exclusion assay), in our cell culture system CFBE41o- cells show a significant reduction in cell viability 6 hours after the introduction of hypoxia (S2A-S2C Fig), which made it necessary to perform experiments for 4 hours. Although this appears to be a short time point for cytokine release, using a similar time point, Veit et al. showed detectable cytokine levels in CFBE41o- cells [60]. 


\section{Canonical / Classical NF-אB}

\section{Alternative NF-KB}

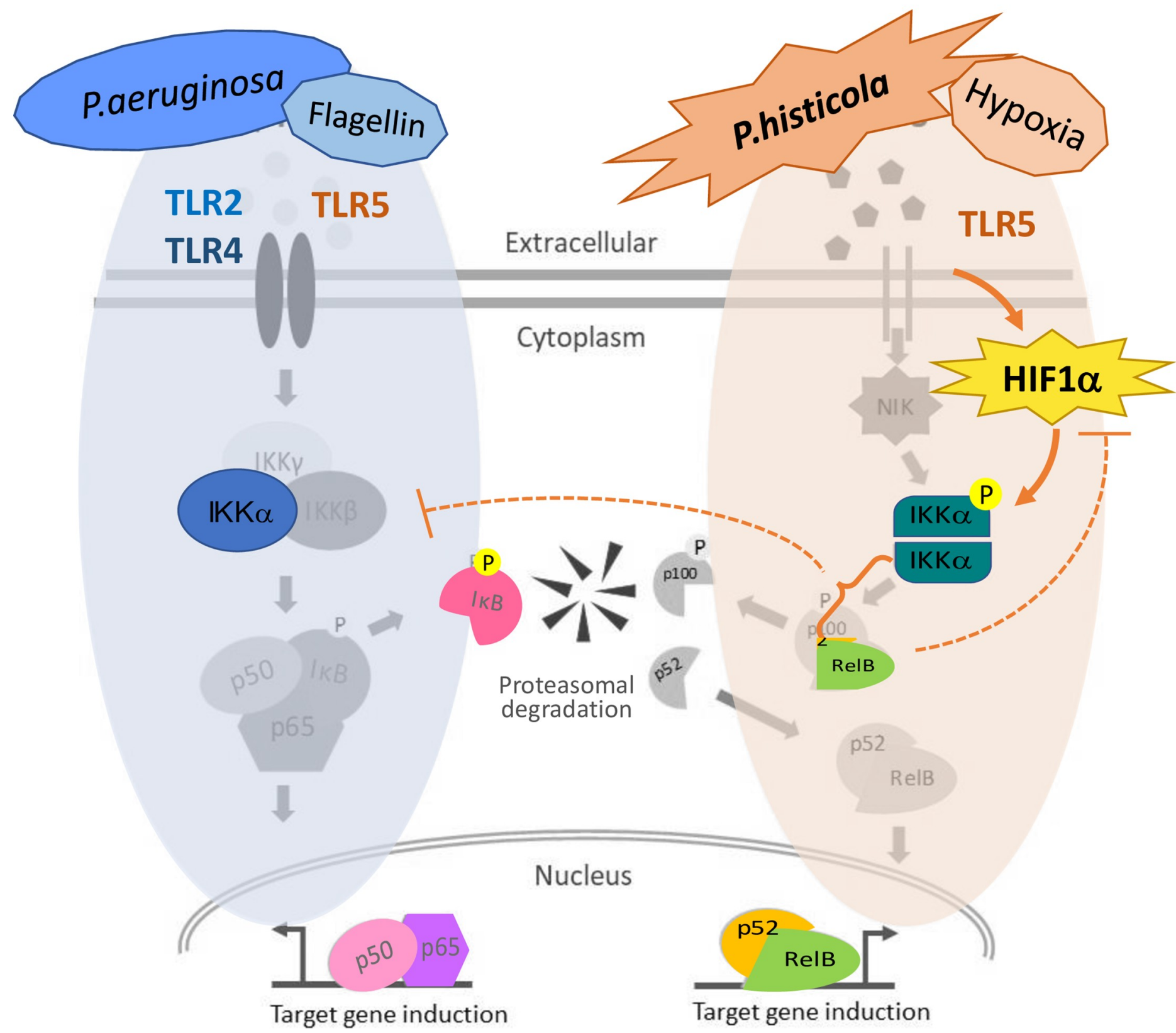

Fig 5. P. histicola signalling-Schematic representation. Canonical NF- $\kappa B$ signalling pathway (left) utilising $\mathrm{p} 65 / \mathrm{p} 50$ and the alternative NF- $\kappa B$ signalling pathway (right) signalling through RelB. While P. aeruginosa and flagellin signal through TLR4 / TLR5-NF- $\kappa B$ (p65), P. histicola signals through TLR5 activating the alternative NF-kB (RelB) pathway. HIF1 $\alpha$ mediates this signalling through activation of IKK $\alpha$. However, RelB might introduce a negative feedback on HIF-1a and may also inhibit IKb $\alpha$. Proteins determined within the study are highlighted in colour.

https://doi.org/10.1371/journal.pone.0235803.g005

A further limitation of this study is the use of only one P. histicola clinical strain. We opted for the comparison of a clinical $P$. histicola strain with a clinical $P$. aeruginosa strain to reflect clinical conditions. Finally, this study was performed in one CF epithelial cell line (CFBE41o- cells) and, as we were interested in the different responses of CF relevant pathogens 
(P. histicola versus P. aeruginosa), we did not perform the experiments in non-CF airway cells or CFTR corrected CF epithelial cells. TLR signalling was also investigated using human embryonic kidney (HEK) 293 reporter cells (InvivoGen), which are specially engineered to constitutively express a given functional pathogen recognition receptor gene and are not expected to express CFTR. Our results need to be confirmed using differentiated primary epithelial cells (CF and non-CF), particularly since mucus production would be expected to contribute to anaerobic conditions in the airway.

Despite these limitations, this study is the first to show the signalling pathway of $P$. histicola in CF bronchial epithelial cells leading to TLR5 activation resulting in the activation of the alternative NF- $\kappa \mathrm{B}$ signalling pathway. Our work also raises the possibility of a flagellin-independent process, which needs further investigation. This is also the first study showing TLR5-RelB signalling for a clinical isolate of $P$. histicola. Furthermore, we have identified a role for IKK $\alpha$ in the regulation of inflammation in response to infection with P. histicola and this may explain the correlation between elevated levels of anaerobes in the microbiome and better lung function in CF patients [29]. Prevotella spp. in the gut microbiome display substantial genomic diversity between strains [61], but these studies have also identified beneficial and detrimental roles for these bacteria, demonstrating that each species may have dual roles in the microbiome and that further studies are required before we can fully appreciate the role of Prevotella spp. in disease and health [62-64].

\section{Conclusion}

Anaerobic bacteria such as Gram-negative Prevotella spp. are frequently found in the airways from healthy volunteers and CF patients, but no studies have examined the role of $P$. histicola in modulating inflammatory pathways in CF airway. Our study demonstrates for the first time important differences in the activation of the NF-kB pathway in anaerobic CF lung inflammation between $P$. histicola and $P$. aeruginosa, and shows a relationship between the alternative NF- $\kappa B$ signalling pathway (utilised by $P$. histicola) and the HIF- $1 \alpha$ signalling pathway (summarised in Fig 5). Overall, our work suggests that different species of bacteria present in the respiratory microbiome can contribute differently to inflammation in the CF lung, either by activating inflammatory cascades (e.g P. aeruginosa) or by muting the inflammatory response to infection by modulating similar or related pathways (as shown for P. histicola). Further work is required to assess the complex interactions of the lung microbiome in response to bacterial infections and their positive effects in people with CF.

\section{Supporting information}

S1 Text. Materials \& methods. (DOCX)

S1 Fig. Growth rate of $P$. histicola and P. aeruginosa. Growth rate of $P$. histicola B011L and $P$. aeruginosa $\mathrm{B} 021$ under anaerobic conditions as described in supporting information above. All data $\mathrm{n}=3-4$ with 2way ANOVA with Bonferroni correction.

S2 Fig. Cell viability under aerobic and anaerobic conditions. (A) Mitochondrial activity of CFBE41o- cells (MTT assay); (B) \% LDH release from CFBE41o- cells and (C) uptake of Trypan blue by CFBE41o- cells incubated under anaerobic and aerobic conditions as described in supporting information above. All data $\mathrm{n}=4$ with 2way ANOVA with Bonferroni correction, ${ }^{*} \mathrm{p}<0.05,{ }^{* *} \mathrm{p}<0.01$.

(TIF) 
S3 Fig. Cell viability during transfection. Lactate dehydrogenase (LDH) release from CFBE41o- cells after 0-96h of transfection with Lipofectamine $2000(0.5-1.5 \mathrm{ng} / \mathrm{ml})$ in the presence and absence of ALL-STARS Hs cell death siRNA (Qiagen) to assess transfection efficiency. All $n=3,{ }^{*} p<0.05$ compared to control. 2-Way ANOVA with Bonferroni post-test, overall ANOVA given within the graph.

S4 Fig. Transfection efficiency for target genes. Efficiency for transfection was assessed by transfecting cells with TLR5 siRNA followed by the addition of either P. histicola (B011L), $P$. aeruginosa and flagellin and calculated relative to the induced response. (A) Significant reduction in TLR5 mRNA (55\% and 60\% in response to $P$. histicola and P. aeruginosa infection, respectively). (B) This was followed by a $\geq 70 \%$ reduction in IL- 6 mRNA (48 hours post transfection).

(TIF)

\section{Acknowledgments}

The authors thank all technical staff of QUB and the Belfast Trust for their help.

\section{Author Contributions}

Conceptualization: Stuart J. Elborn.

Data curation: Anne Bertelsen, Stuart J. Elborn.

Formal analysis: Anne Bertelsen, Bettina C. Schock.

Funding acquisition: Stuart J. Elborn.

Investigation: Anne Bertelsen.

Methodology: Anne Bertelsen, Bettina C. Schock.

Resources: Stuart J. Elborn.

Supervision: Stuart J. Elborn, Bettina C. Schock.

Validation: Anne Bertelsen.

Visualization: Anne Bertelsen, Bettina C. Schock.

Writing - original draft: Anne Bertelsen.

Writing - review \& editing: Stuart J. Elborn, Bettina C. Schock.

\section{References}

1. Elborn JS. 2016. Cystic fibrosis. Lancet 388:2519-2531. https://doi.org/10.1016/S0140-6736(16) 00576-6 PMID: 27140670

2. Brennan S. 2008. Innate immune activation and cystic fibrosis. Paediatr Respir Rev 9:271-9; quiz 27980. https://doi.org/10.1016/j.prrv.2008.05.008 PMID: 19026368

3. Bevivino A, Bacci G, Drevinek P, Nelson MT, Hoffman L, Mengoni A. 2019. Deciphering the Ecology of Cystic Fibrosis Bacterial Communities: Towards Systems-Level Integration. Trends Mol Med 25:11101122. https://doi.org/10.1016/j.molmed.2019.07.008 PMID: 31439509

4. Tang AC, Turvey SE, Alves MP, Regamey N, Tummler B, Hartl D. 2014. Current concepts: host-pathogen interactions in cystic fibrosis airways disease. Eur Respir Rev 23:320-32. https://doi.org/10.1183/ 09059180.00006113 PMID: 25176968

5. Zemanick ET, Hoffman LR. 2016. Cystic Fibrosis: Microbiology and Host Response. Pediatr Clin North Am 63:617-36. https://doi.org/10.1016/j.pcl.2016.04.003 PMID: 27469179 
6. Tunney MM, Field TR, Moriarty TF, Patrick S, Doering G, Muhlebach MS, et al. 2008. Detection of anaerobic bacteria in high numbers in sputum from patients with cystic fibrosis. Am J Respir Crit Care Med 177:995-1001. https://doi.org/10.1164/rccm.200708-11510C PMID: 18263800

7. Busch DF, Kureshi LA, Sutter VL, Finegold SM. 1976. Susceptibility of respiratory tract anaerobes to orally administered penicillins and cephalosporins. Antimicrob Agents Chemother 10:713-20. https:// doi.org/10.1128/aac.10.4.713 PMID: 984805

8. Zemanick ET, Harris JK, Wagner BD, Robertson CE, Sagel SD, Stevens MJ, et al. 2013. Inflammation and airway microbiota during cystic fibrosis pulmonary exacerbations. PLoS One 8:e62917. https://doi. org/10.1371/journal.pone.0062917 PMID: 23646159

9. Bertelsen A, Elborn JS, Schock BC. 2019. Infection with Prevotella nigrescens induces TLR2 signalling and low levels of p65 mediated inflammation in Cystic Fibrosis bronchial epithelial cells. Journal of Cystic Fibrosis.

10. Gilmore TD. 2006. Introduction to NF-kappaB: players, pathways, perspectives. Oncogene 25:6680-4. https://doi.org/10.1038/sj.onc.1209954 PMID: 17072321

11. Moynagh PN. 2005. The NF-kappaB pathway. J Cell Sci 118:4589-92. https://doi.org/10.1242/jcs. 02579 PMID: 16219681

12. Sun SC. 2017. The non-canonical NF-kappaB pathway in immunity and inflammation. Nat Rev Immunol 17:545-558. https://doi.org/10.1038/nri.2017.52 PMID: 28580957

13. Blackwell TS, Stecenko AA, Christman JW. 2001. Dysregulated NF-kappaB activation in cystic fibrosis: evidence for a primary inflammatory disorder. Am J Physiol Lung Cell Mol Physiol 281:L69-70. https:// doi.org/10.1152/ajplung.2001.281.1.L69 PMID: 11404247

14. Kelly C, Williams MT, Mitchell K, Elborn JS, Ennis M, Schock BC. 2013. Expression of the nuclear factor-kappaB inhibitor A20 is altered in the cystic fibrosis epithelium. Eur Respir J 41:1315-23. https://doi. org/10.1183/09031936.00032412 PMID: 23018911

15. Pattison SH, Gibson DS, Johnston E, Peacock S, Rivera K, Tunney MM, et al. 2017. Proteomic profile of cystic fibrosis sputum cells in adults chronically infected with Pseudomonas aeruginosa. Eur Respir J 50.

16. Sun SC. 2012. The noncanonical NF-kappaB pathway. Immunol Rev 246:125-40. https://doi.org/10. 1111/j.1600-065X.2011.01088.x PMID: 22435551

17. Tully JE, Hoffman SM, Lahue KG, Nolin JD, Anathy V, Lundblad LK, et al. 2013. Epithelial NF-kappaB orchestrates house dust mite-induced airway inflammation, hyperresponsiveness, and fibrotic remodeling. J Immunol 191:5811-21. https://doi.org/10.4049/jimmunol.1301329 PMID: 24227776

18. Lawrence T, Bebien M, Liu GY, Nizet V, Karin M. 2005. IKKalpha limits macrophage NF-kappaB activation and contributes to the resolution of inflammation. Nature 434:1138-43. https://doi.org/10.1038/ nature03491 PMID: 15858576

19. Schaible B, Schaffer K, Taylor CT. 2010. Hypoxia, innate immunity and infection in the lung. Respir Physiol Neurobiol 174:235-43. https://doi.org/10.1016/j.resp.2010.08.006 PMID: 20709192

20. Chillappagari S, Venkatesan S, Garapati V, Mahavadi P, Munder A, Seubert A, et al. 2014. Impaired TLR4 and HIF expression in cystic fibrosis bronchial epithelial cells downregulates hemeoxygenase-1 and alters iron homeostasis in vitro. Am J Physiol Lung Cell Mol Physiol 307:L791-9. https://doi.org/10. 1152/ajplung.00167.2014 PMID: 25239913

21. Lawrence T. 2009. The nuclear factor NF-kappaB pathway in inflammation. Cold Spring Harb Perspect Biol 1:a001651. https://doi.org/10.1101/cshperspect.a001651 PMID: 20457564

22. Gilpin DF, Nixon KA, Bull M, McGrath SJ, Sherrard L, Rolain JM, et al. 2017. Evidence of persistence of Prevotella spp. in the cystic fibrosis lung. J Med Microbiol https://doi.org/10.1099/jmm.0.000500:825832

23. Buchanan PJ, Ernst RK, Elborn JS, Schock B. 2009. Role of CFTR, Pseudomonas aeruginosa and Toll-like receptors in cystic fibrosis lung inflammation. Biochem Soc Trans 37:863-7. https://doi.org/10 1042/BST0370863 PMID: 19614608

24. Raoust E, Balloy V, Garcia-Verdugo I, Touqui L, Ramphal R, Chignard M. 2009. Pseudomonas aeruginosa LPS or flagellin are sufficient to activate TLR-dependent signaling in murine alveolar macrophages and airway epithelial cells. PLoS One 4:e7259. https://doi.org/10.1371/journal.pone.0007259 PMID: 19806220

25. Zhang Z, Louboutin JP, Weiner DJ, Goldberg JB, Wilson JM. 2005. Human airway epithelial cells sense Pseudomonas aeruginosa infection via recognition of flagellin by Toll-like receptor 5 . Infect Immun 73:7151-60. https://doi.org/10.1128/IAI.73.11.7151-7160.2005 PMID: 16239509

26. Carbia-Nagashima A, Gerez J, Perez-Castro C, Paez-Pereda M, Silberstein S, Stalla GK, et al. 2007. RSUME, a small RWD-containing protein, enhances SUMO conjugation and stabilizes HIF-1alpha during hypoxia. Cell 131:309-23. https://doi.org/10.1016/j.cell.2007.07.044 PMID: 17956732 
27. Roussel L, Martel G, Berube J, Rousseau S. 2011. P. aeruginosa drives CXCL8 synthesis via redundant toll-like receptors and NADPH oxidase in CFTRF508 airway epithelial cells. J Cyst Fibros 10:10713. https://doi.org/10.1016/j.jcf.2010.11.005 PMID: 21176887

28. Muhlebach MS, Hatch JE, Einarsson GG, McGrath SJ, Gilipin DF, Lavelle G, et al. 2018. Anaerobic bacteria cultured from cystic fibrosis airways correlate to milder disease: a multisite study. Eur Respir J 52.

29. O'Neill K, Bradley JM, Johnston E, McGrath S, Mcllreavey L, Rowan S, et al. 2015. Reduced bacterial colony count of anaerobic bacteria is associated with a worsening in lung clearance index and inflammation in cystic fibrosis. PLoS One 10:e0126980. https://doi.org/10.1371/journal.pone.0126980 PMID: 25992575

30. Larsen JM, Musavian HS, Butt TM, Ingvorsen C, Thysen AH, Brix S. 2015. Chronic obstructive pulmonary disease and asthma-associated Proteobacteria, but not commensal Prevotella spp., promote Tolllike receptor 2-independent lung inflammation and pathology. Immunology 144:333-42. https://doi.org/ 10.1111/imm.12376 PMID: 25179236

31. Marietta EV, Murray JA, Luckey DH, Jeraldo PR, Lamba A, Patel R, et al. 2016. Suppression of Inflammatory Arthritis by Human Gut-Derived Prevotella histicola in Humanized Mice. Arthritis Rheumatol 68:2878-2888. https://doi.org/10.1002/art.39785 PMID: 27337150

32. Schaible B, McClean S, Selfridge A, Broquet A, Asehnoune K, Taylor CT, et al. 2013. Hypoxia modulates infection of epithelial cells by Pseudomonas aeruginosa. PLoS One 8:e56491. https://doi.org/10. 1371/journal.pone.0056491 PMID: 23418576

33. Greene CM, Carroll TP, Smith SG, Taggart CC, Devaney J, Griffin S, et al. 2005. TLR-induced inflammation in cystic fibrosis and non-cystic fibrosis airway epithelial cells. J Immunol 174:1638-46. https:// doi.org/10.4049/jimmunol.174.3.1638 PMID: 15661927

34. John G, Yildirim AO, Rubin BK, Gruenert DC, Henke MO. 2010. TLR-4-mediated innate immunity is reduced in cystic fibrosis airway cells. Am J Respir Cell Mol Biol 42:424-31. https://doi.org/10.1165/ rcmb.2008-0408OC PMID: 19502387

35. Kelly C, Canning P, Buchanan PJ, Williams MT, Brown V, Gruenert DC, et al. 2013. Toll-like receptor 4 is not targeted to the lysosome in cystic fibrosis airway epithelial cells. Am J Physiol Lung Cell Mol Physiol 304:L371-82. https://doi.org/10.1152/ajplung.00372.2011 PMID: 23316065

36. Kosamo S, Hisert KB, Dmyterko V, Nguyen C, Black RA, Holden TD, et al. 2020. Strong toll-like receptor responses in cystic fibrosis patients are associated with higher lung function. J Cyst Fibros 19:608613. https://doi.org/10.1016/j.jcf.2019.11.009 PMID: 31813753

37. Xia Y, Pauza ME, Feng L, Lo D. 1997. RelB regulation of chemokine expression modulates local inflammation. Am J Pathol 151:375-87. PMID: 9250151

38. Weih F, Carrasco D, Durham SK, Barton DS, Rizzo CA, Ryseck RP, et al. 1995. Multiorgan inflammation and hematopoietic abnormalities in mice with a targeted disruption of RelB, a member of the NFkappa B/Rel family. Cell 80:331-40. https://doi.org/10.1016/0092-8674(95)90416-6 PMID: 7834753

39. McMillan DH, Woeller CF, Thatcher TH, Spinelli SL, Maggirwar SB, Sime PJ, et al. 2013. Attenuation of inflammatory mediator production by the NF-kappaB member RelB is mediated by microRNA-146a in lung fibroblasts. Am J Physiol Lung Cell Mol Physiol 304:L774-81. https://doi.org/10.1152/ajplung. 00352.2012 PMID: 23564509

40. Chen X, Yoza BK, El Gazzar M, Hu JY, Cousart SL, McCall CE. 2009. RelB sustains IkappaBalpha expression during endotoxin tolerance. Clin Vaccine Immunol 16:104-10. https://doi.org/10.1128/CVI. 00320-08 PMID: 19020113

41. Yoza BK, Hu JY, Cousart SL, Forrest LM, McCall CE. 2006. Induction of RelB participates in endotoxin tolerance. J Immunol 177:4080-5. https://doi.org/10.4049/jimmunol.177.6.4080 PMID: 16951372

42. Xia Y, Chen S, Wang Y, Mackman N, Ku G, Lo D, et al. 1999. RelB modulation of IkappaBalpha stability as a mechanism of transcription suppression of interleukin-1alpha (IL-1alpha), IL-1beta, and tumor necrosis factor alpha in fibroblasts. Mol Cell Biol 19:7688-96. https://doi.org/10.1128/mcb.19.11.7688 PMID: 10523657

43. Saccani S, Pantano S, Natoli G. 2003. Modulation of NF-kappaB activity by exchange of dimers. Mol Cell 11:1563-74. https://doi.org/10.1016/s1097-2765(03)00227-2 PMID: 12820969

44. Marienfeld R, May MJ, Berberich I, Serfling E, Ghosh S, Neumann M. 2003. RelB forms transcriptionally inactive complexes with RelA/p65. J Biol Chem 278:19852-60. https://doi.org/10.1074/jbc. M301945200 PMID: 12657634

45. Jacque E, Tchenio T, Piton G, Romeo PH, Baud V. 2005. RelA repression of RelB activity induces selective gene activation downstream of TNF receptors. Proc Natl Acad Sci U S A 102:14635-40. https://doi.org/10.1073/pnas.0507342102 PMID: 16192349 
46. Devi YS, DeVine M, DeKuiper J, Ferguson S, Fazleabas AT. 2015. Inhibition of IL-6 signaling pathway by curcumin in uterine decidual cells. PLoS One 10:e0125627. https://doi.org/10.1371/journal.pone. 0125627 PMID: 25961579

47. Steiner TS. 2007. How flagellin and toll-like receptor 5 contribute to enteric infection. Infect Immun 75:545-52. https://doi.org/10.1128/IAI.01506-06 PMID: 17118981

48. Campodonico VL, Llosa NJ, Grout M, Doring G, Maira-Litran T, Pier GB. 2010. Evaluation of flagella and flagellin of Pseudomonas aeruginosa as vaccines. Infect Immun 78:746-55. https://doi.org/10. 1128/IAI.00806-09 PMID: 19995892

49. Wolfgang MC, Jyot J, Goodman AL, Ramphal R, Lory S. 2004. Pseudomonas aeruginosa regulates flagellin expression as part of a global response to airway fluid from cystic fibrosis patients. Proc Natl Acad Sci U S A 101:6664-8. https://doi.org/10.1073/pnas.0307553101 PMID: 15084751

50. Rolli J, Loukili N, Levrand S, Rosenblatt-Velin N, Rignault-Clerc S, Waeber B, et al. 2010. Bacterial flagellin elicits widespread innate immune defense mechanisms, apoptotic signaling, and a sepsis-like systemic inflammatory response in mice. Crit Care 14:R160. https://doi.org/10.1186/cc9235 PMID: 20731882

51. Tallant T, Deb A, Kar N, Lupica J, de Veer MJ, DiDonato JA. 2004. Flagellin acting via TLR5 is the major activator of key signaling pathways leading to NF-kappa B and proinflammatory gene program activation in intestinal epithelial cells. BMC Microbiol 4:33. https://doi.org/10.1186/1471-2180-4-33 PMID: 15324458

52. Blohmke CJ, Victor RE, Hirschfeld AF, Elias IM, Hancock DG, Lane CR, et al. 2008. Innate immunity mediated by TLR5 as a novel antiinflammatory target for cystic fibrosis lung disease. $\mathrm{J}$ Immunol 180:7764-73. https://doi.org/10.4049/jimmunol.180.11.7764 PMID: 18490781

53. Ruan Y, Shen L, Zou Y, Qi Z, Yin J, Jiang J, et al. 2015. Comparative genome analysis of Prevotella intermedia strain isolated from infected root canal reveals features related to pathogenicity and adaptation. BMC Genomics 16:122. https://doi.org/10.1186/s12864-015-1272-3 PMID: 25765460

54. Xu ZZ, Kim YH, Bang S, Zhang Y, Berta T, Wang F, et al. 2015. Inhibition of mechanical allodynia in neuropathic pain by TLR5-mediated A-fiber blockade. Nat Med 21:1326-31. https://doi.org/10.1038/ nm.3978 PMID: 26479925

55. Pachathundikandi SK, Tegtmeyer N, Arnold IC, Lind J, Neddermann M, Falkeis-Veits C, et al. 2019. T4SS-dependent TLR5 activation by Helicobacter pylori infection. Nat Commun 10:5717. https://doi. org/10.1038/s41467-019-13506-6 PMID: 31844047

56. Lee JW, Ko J, Ju C, Eltzschig HK. 2019. Hypoxia signaling in human diseases and therapeutic targets. Exp Mol Med 51:1-13.

57. Eckle T, Brodsky K, Bonney M, Packard T, Han J, Borchers $\mathrm{CH}$, et al. 2013. HIF1A reduces acute lung injury by optimizing carbohydrate metabolism in the alveolar epithelium. PLoS Biol 11:e1001665. https://doi.org/10.1371/journal.pbio.1001665 PMID: 24086109

58. Peyssonnaux C, Cejudo-Martin P, Doedens A, Zinkernagel AS, Johnson RS, Nizet V. 2007. Cutting Edge: Essential Role of Hypoxia Inducible Factor-1 $\alpha$ in Development of Lipopolysaccharide-Induced Sepsis. The Journal of Immunology 178:7516. https://doi.org/10.4049/jimmunol.178.12.7516 PMID: 17548584

59. Scheller J, Chalaris A, Schmidt-Arras D, Rose-John S. 2011. The pro- and anti-inflammatory properties of the cytokine interleukin-6. Biochimica et Biophysica Acta (BBA)-Molecular Cell Research 1813:878-888.

60. Veit G, Bossard F, Goepp J, Verkman AS, Galietta LJ, Hanrahan JW, et al. 2012. Proinflammatory cytokine secretion is suppressed by TMEM16A or CFTR channel activity in human cystic fibrosis bronchial epithelia. Mol Biol Cell 23:4188-202. https://doi.org/10.1091/mbc.E12-06-0424 PMID: 22973054

61. Tambo T, Kuriyama T, Karasawa T, Nakagawa K, Yamamoto E, Williams DW. 2010. Genetic Hetrogeneity of Prevotella Strains Involved in Dentoalveolar Abscess. Archives of Clinical Microbiology 1.

62. Dillon SM, Lee EJ, Kotter CV, Austin GL, Gianella S, Siewe B, et al. 2016. Gut dendritic cell activation links an altered colonic microbiome to mucosal and systemic T-cell activation in untreated HIV-1 infection. Mucosal Immunol 9:24-37. https://doi.org/10.1038/mi.2015.33 PMID: 25921339

63. Scher JU, Sczesnak A, Longman RS, Segata N, Ubeda C, Bielski C, et al. 2013. Expansion of intestinal Prevotella copri correlates with enhanced susceptibility to arthritis. Elife 2:e01202. https://doi.org/10. 7554/eLife.01202 PMID: 24192039

64. Wu GD, Chen J, Hoffmann C, Bittinger K, Chen YY, Keilbaugh SA, et al. 2011. Linking long-term dietary patterns with gut microbial enterotypes. Science 334:105-8. https://doi.org/10.1126/science.1208344 PMID: 21885731 